\title{
Characteristics of Mexican Leather Footwear Industry and its International Trade Activity, Correlation of Productivity, and Competitiveness
}

\author{
Y. D. Cisneros-Reyes (MA) \\ J. E. Rocha-Ibarra (PhD) \\ M. G. Arredondo-Hidalgo (PhD) \\ University of Guanajuato, Mexico
}

Doi:10.19044/esj.2018.v14n22p63ＵRL:http://dx.doi.org/10.19044/esj.2018.v14n22p63

\begin{abstract}
This paper focuses on analyzing the globalization effect on the Mexican leather footwear industry at a firm-level. In this work, the analysis of competitiveness is done based on the definition given by the Organization for Economic Cooperation and Development (OECD). They defined it as 'a measure of a country's advantage or disadvantage in selling its products in international market'. The productivity of the Mexican leather footwear industry was calculated using the Latin American-KLEMS Model that relates gross output to primary (Capital and Labor) and intermediate inputs (Energy, Other intermediate goods, and Services). Furthermore, firms were categorized considering the number of employees, the annual value of production, and the commercial diversification in order to calculate the correlation Pearson coefficient. Firstly, the results show that the correlation of production value with the number of exporting companies is bigger than the correlation of the importing companies. Secondly, that the correlation of Total Productivity Factor (TPF) to exports is strong (0.7028); and finally, that the correlation of Total Productivity Factor (TPF) to imports is also significant (0.6511).
\end{abstract}

Keywords: Competitiveness, Productivity, Firm-level, Imports, Exports

\section{Introduction}

Globalizations, as an economic process, generate different effects in terms of magnitude and direction in every region, country, and industry. Thus, even firms are involved in this phenomenon, and they are often considered as natural as well as controversial.

According to Kuepper (2016), most economists agree that globalization provides a net benefit to individual economies around the world, by making markets more efficient, increasing competition, limiting military 
conflicts, and spreading wealth more equally around the world. However, the general public tends to assume that the costs associated with globalization outweigh the benefits. Therefore, this is the idea that prevails in the minds of the entrepreneurs that manages Small and Medium Enterprises (SMEs) of the Mexican footwear industry.

Net benefit implies that some countries and industries obtain more profit than others. It is interesting to analyze that the result depends not only on the stages of development of the country, but also on the particular characteristics of the economic sector and even more on the firm-level characteristics. This paper focuses on analyzing the effect of globalization on the Mexican leather footwear industry of the period 2007-2013 due to the absence of recent studies that try to find out the correlation between productivity and competitiveness in this sector. For this study, it is considered the definition of competitiveness given by OECD: 'a measure of a country's advantage or disadvantage in selling its products in international markets' (OECD, 2014). The productivity of Mexican leather footwear industry was measured according to LA-KLEMS. This project, however, created a database on measures of economic growth, productivity, employment creation, capital formation and technological change at the industry level, initially for all European Union member stated from 1970 onwards, and later on extended to some other economies of the world (CEPAL, 2016).

The rest of this paper is organized as follows: In section 2 , the recent literature is reviewed. In section 3, information of Mexican leather footwear industry is presented and the firms are categorized considering the number of employees, the value of annual production, and the commercial diversification. In section 4, the methodology used to get the Total Productivity Factor TPF of Mexican leather footwear industry is described. Section 5 presents the results of Pearson correlation coefficient followed by Section 6 where the results are discussed and the conclusions are presented.

\section{Literature Review}

According to the theory of comparative advantages, if countries in international trade specialize in producing the goods and products, in which their relative labor productivity or their relative expenditure cost is more favorable, that will lead to the development of an international division of labor, from which each country benefits (Krugman, 1994, 2002).

The theory of competitive advantages reflects the new conditions of the global competition. Porter (1998) claims that today the theory of comparative advantages does not provide an acceptable explanation about the international division of labor. Porter's proposal (1998) on development is the theory of competitive advantages, which systematizes the development phases of countries and the new elements of the international and regional division of 
labor. The competitive advantage of a given country or region depends on the economic structure, the development level of the institution system and the quality of its operation, the governmental economic policies, and the ideas of regional development.

The competitive strategies of global companies and the regional clusters exploit dynamic agglomeration economies. Defining the new economics of competition, Porter (2001) highlights six fundamental factors: level, focus, addresses, economic and social policy, geographical unit, and sources of company success.

Lately, and favored by the increasing availability of data, some researchers have been concerned to distinguish the economical behaviour of the two main actors in international trade: importers and exporters, considering the particular characteristics of the firms of both groups.

In their review of firms from the United States in international trade, Bernard (2007) draws attention to the strong correlation (0.87) between industries with high shares of importing firms and those with high shares of exporters. They found out that $79 \%$ of importers also export. Their descriptive analysis shows that both types of firms show many similarities in their performance measures. Both exporters and importers are more productive, larger, capital, and skill intensive than firms that do not have any trading relationships with the rest of the world. However, they do not split firms into separate groups to show how firms that perform both activities differ from the other group of firms. Moreover, they do not analyze how firms in different trade groups differ in growth performances.

In another study, Muuls (2009) analyzes Belgium firms and divides them into four trading groups as two-way traders (both, importing and exporting), only exporters, only importers, and non-traders. Thus, a positive relationship was found between labor productivity and importing for Belgium firms.

Vogel (2010) performs a similar analysis for German manufacturing firms. In addition to show the positive link between importing and labor productivity, evidence on the direction of causality in this relationship was found. The significance of self-selection of more productive firms into importing and learning effects of importing was also studied. As a result, evidence on the self-selection hypothesis was also found.

Although analyzing these studies are informative, none of them analyze firm growth and their contribution to the Total Production of Factors according to the KLEMS model. In addition, their conclusions on the two-way traders are more productive and larger, and it only shows indirectly these firms' higher growth potential.

Moreover, Vogel (2010) uses turnover per employee as their measure of labor productivity. This measure, as well as other measures of labor 
productivity, suffers from the unobserved price effects on measuring productivity. As Seker (2011) mentions, it is difficult to isolate firm's intrinsic efficiency with these measures.

Consequently, the practice of considering just exporting performance as the trade variable of interest is often criticized. Estefahani (1991) uses threestage cross-country equation systems to show the importance of including importing activities. Investigating 31 semi-industrialized countries, Estefahani concluded that exports' primary contribution is to finance the import of intermediate products.

In addition, Awokuse (2008) mentioned that little attention has been paid to the importance of imports. In his research, he used a quarterly data for three Latin-American countries from the beginning of the 1990's to April 2002. By considering real Gross Domestic Product (GDP) growth, real exports, real imports, gross capital formation and labor force concluded that 'the exclusion of imports and singular focus of many past studies on just the role of export as the engine of growth may be misleading or at best incomplete'.

Ifwarson (2010) establishes that difference between countries growth rates can be explained only partly by increases in the employment of the basic factors of production: capital and labor. Instead, the differences are mainly due to different rates of increase in productivity of the inputs'.

Aghion (2009) opined that it is possible that long-run income growth might be rather caused by technological progress in this study. LA-KLEMS Model (Latin America Capital, Labor, Energy, Materials and Services) is used because it is included as an ICT's factor (Information and Communication Technologies) and other related aspects were also included.

Kunst (1989) establishes that focus should be on productivity rather than income, supporting the idea of calculating the Pearson product-moment correlation coefficient that takes into account the Total Factor Productivity (TPF).

Since the seminal works of Grossman (1991), Aghion (2005) and Romer (1990), many studies have found technological innovation to be the main determinant of growth.

\section{Footwear Industry}

\subsection{Global Panorama}

The textile and footwear industry is vital for the economy of some countries, both in terms of the number of people it employs and the revenues it generates. In the last half century, this industry - which was concentrated in industrialized nations in the mid-twentieth century - has gradually spread to developing countries. The global 'redistribution' of this industry began in the late 1960 s, with the expansion of new manufacturing centers in Asia. In some 
cases, particularly in South Asia, imported fabrics were progressively substituted with national ones as a domestic textile industry began to take shape.

Many developing countries applied this strategy and, over the last 20 years, textile (including footwear) production has grown at an average global rate of $1.2 \%$, with variations depending on the level of development of the country in question. In more industrialized economies, for example, growth has averaged $2.7 \%$, compared to $3.6 \%$ in Asia (Tradegood, 2013).

Nonetheless, many developed countries still have viable textile industries that operate mainly at the top end of the market. And thanks to restructuring and modernization measures, several of them still features on the list of the world's top ten textile exporters in terms of the value of their products.

Nowadays, global shoe production stands at 24 billion pairs a year, $60 \%$ of which are exported. Global trade in non-sporting footwear is valued at approximately US\$15 billion a year. Footwear with leather uppers accounts for a massive $85 \%$ of this total (Tradegood, 2013).

China alone produces approximately 9.5 billion pairs a year, 7 billion of which are exported. The most spectacular growth has probably been posted by China and India -which manufactures 700 million pairs of shoes a yearousting countries like Italy that were once major producers, but whose annual output has now fallen to 400 million pairs (Tradegood, 2013).

Brazil is an interesting, but equally successful case that falls somewhere between the Chinese and Italian models. In the last 25 years, the country has tripled its output and positioned itself among the large global exporters. This is largely due to its strategy of supplying the USA with ladies' shoes in the medium-to-low price range. Annual shoe exports are valued at US\$1.6 billion, 70\% of which -mainly ladies' shoes- are intended for the USA, where Brazil is the leading supplier of women's footwear with a $42 \%$ market share, followed by China with $38 \%$ and Italy with $10 \%$ (Tradegood, 2013).

\subsection{Mexican Footwear Industry Panorama}

The footwear industry is important for the Mexican economy due to the fact that in 2015, they produced 251,000,000 pair of shoes that accounts for $0.43 \%$ of the Gross Domestic Product (GDP) and $0.90 \%$ if considered the complete productive chain of the sector. Thus, about 11,538 firms were able to employ 579,000 people (INEGI National Institute of Geography, Statistics and Informatics, 2015).

Figure 1 shows that Mexican footwear industry is heavily concentrated in eight cities of the country: a) Leon, Guanajuato $(57.8 \%$ of total value production), b) Guadalajara, Jalisco (10\%), c) San Francisco del Rincon, 
Guanajuato (6.7\%), d) Purisima del Rincon, Guanajuato (3.9\%), e) Zapopan, Jalisco (3.1\%), f) Iztapalapa, City of Mexico (1.4\%), g) Toluca, Mexico State $(1.3 \%)$, and h) San Mateo Atenco, Mexico State (1.2\%). However, they represent $85.4 \%$ of the national production of the sector (CICEG Chamber of the Footwear Industry of Guanajuato State, 2015).

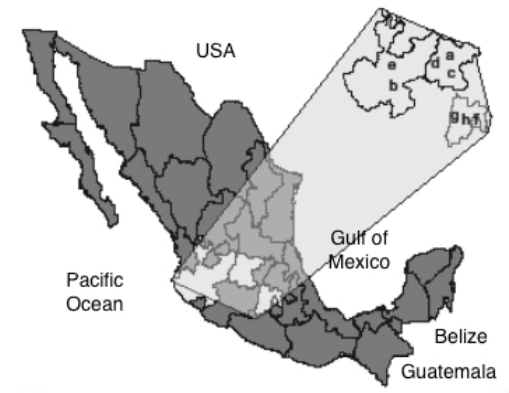

Figure 1. Concentration of Mexican footwear industry Data source: (INEGI, 2014)

According to APICCAPS, the Portuguese Footwear, Components and Leather Goods Manufacturers' Association (2015), Mexicans buy around 303 million pairs of shoes a year, which translates into about 2.5 pairs per capita (CICEG Chamber of the Footwear Industry of Guanajuato State, 2015).

\subsubsection{International Trade}

As reported in CICEG (2015), 27,496,141 pairs of the 251 million pairs of shoes that the country manufactured in 2015 were exported. In that year, exports reached \$552,321,104 USD, positioning Mexico in value world ranking 26th (volume world ranking 27th), while imports stood at 80,041,098 pairs $(965,328,657$ USD) with the volume world ranking 25th (value world ranking 21st). The main international market for Mexican-made shoes was USA $(76.17 \%)$, followed by Netherlands $(5.08 \%)$, Guatemala $(4.19 \%)$, Colombia (2.66\%), Panama (1.70\%), Japan (1.31\%), Chile (1.19\%) and others (7.7\%) (AGA, 2015).

Subsequently, the most important product exported by the Mexican footwear industry is footwear made with leather upper that accounted for $74.3 \%$ in 2013 . Ten countries received $94.1 \%$ of these exportations, and it is important to highlight that the USA received $82.6 \%$ of these products during that year (INEGI, 2014).

On the other hand, in terms of imports in 2015, China provided 55\% of the pair of shoes followed by Vietnam (27\%), Indonesia (7\%), Spain (2\%), and others (9\%) (AGA, 2015).

In the 1990s, the Mexican footwear industry benefited from the dismantling of trade barriers, particularly the lifting of duties provided by the North American Free Trade Agreement (NAFTA). However, since 2000, the 
industry has faced growing competition from countries like China, a situation that was compounded when the latter joined the World Trade Organization (WTO). On the upside, fiercer competition has forced the sector to take stock and shore up its activities (Tradegood, 2013).

There is evidence that Mexican footwear industry production has been increasing, in 2013 even more than the rest of the Mexican manufacturing industry rate. However, during the studied period (2007-2013), the exportation activity is mixed with a decrease during 2007-2010 and an increase during 2011-2013. Thus, this is followed by a decrease registered in 2014 .

These results might be ambiguous but it is important to consider the volume of Mexican footwear exports to USA. Its biggest market is as follows: for $77 \%$ in $2007,85.2 \%$ in 2009, 81.5\% in 2011, and 82.6\% in 2013 (INEGI National Institute of Geography, 2014).

Then, considering the definition of competitiveness formulated by OECD that compares both international trade activities: imports and exports, these results might imply a loss of competitiveness for Mexican footwear industry since imports for this same industry have been increasing during the period 2007-2013, except in 2009. In fact, since 2002, the Mexican footwear industry registered a commercial deficit that points for a decline in the global competitiveness ranking.

It is also significant to mention that in 2013, the most important product imported by Mexico was footwear made of fabrics (32.9\%), followed in second place by footwear with uppers of leather (31.9\%), and in third place by footwear made of rubber or plastic (27.4\%). In 2013, 96.4\% of footwear products were imported from ten different countries of which $77.5 \%$ was imported from only 3 of them: China (35.4\%), Vietnam (29.9\%), and Indonesia (12.2\%) (INEGI National Institute of Geography, 2014).

In general terms, a few firms, that are also the largest of the industry, carry out both imports and exports. In 2012, 58.1\% of exports were concentrated by only 23 companies, and 28 firms realized $70.9 \%$ of imports. However, in 2013, 213 companies had exporting activity and 185 importing activity (INEGI National Institute of Geography, 2014). These facts gives evidence that Mexican firms are not able to face globalization process and the size of the companies is one of the factors that must be considered to understand why this occurs. For this reason, firm level analysis was made considering different variables: number of employees, annual value of production, and commercial diversification. Figure 2 and Figure 3 show graphically the evolution of the Mexican footwear-exporting firms by number of employees from 2007 to 2013. 


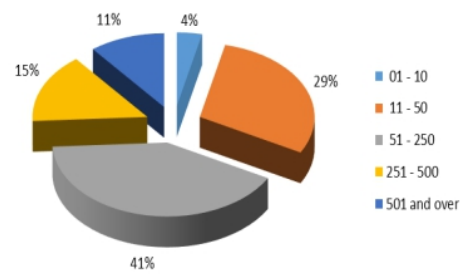

Figure 2. Mexican footwear-exporting firms by number of employees (2007)

Source: Authors' elaboration

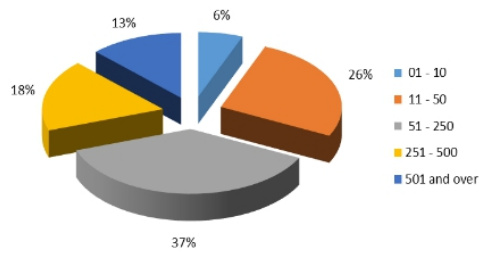

Figure 3. Mexican footwear-exporting firms by number of employees (2013)

Source: Authors' elaboration

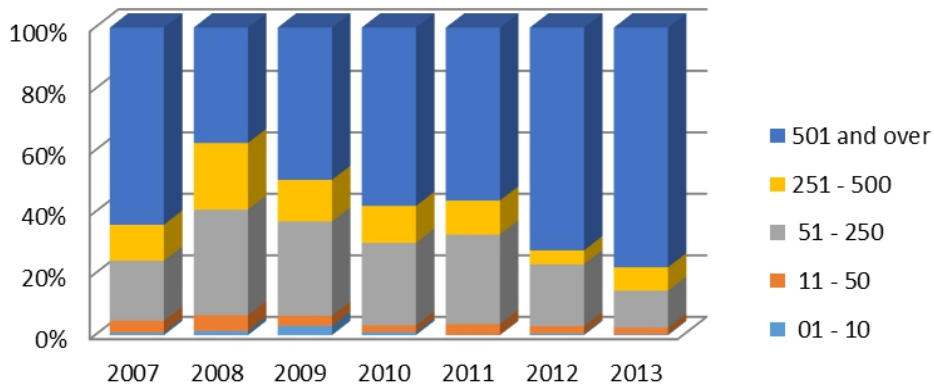

Figure 4. Mexican footwear volume exports (thousands of USD) by number of employees (2007-2013)

Source: Authors' elaboration

Analysing the information presented in Figure 4, it can be observed that large footwear exporting firms (251-500 employees and $501->$ ) have become more important through period 2007-2013. Therefore, one of the implications of this fact was registered in 2008, when the international financial crisis of USA shows that exportations of these 2 groups fall around $48 \%$. Only 5 years later, this difficulty was overcome. It is also important to notice that in 2013, the recovery has not been possible for medium (51-250), small (11-50), and micro (01-10) organizations that have not reached the level of exportations of 2007. This is a first approach to the way in which the size of the organizations of this industry influences the way in which they face the economic difficulties and, in general, the world competition. The productivity 
of organizations and relations with international trade activity will be discussed later in section 4.

Continuing with the analysis in terms of number of employees, Figure 4 and Figure 5 show graphically the evolution of the Mexican footwearimporting firms from 2007 to 2013.

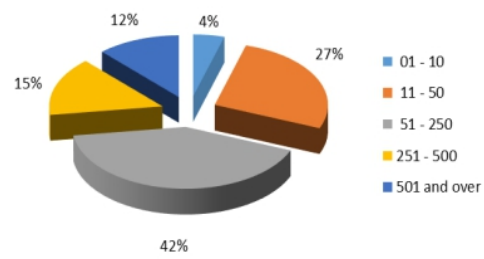

Figure 5. Mexican footwear-importing firms by number of employees (2007)

Source: Authors' elaboration

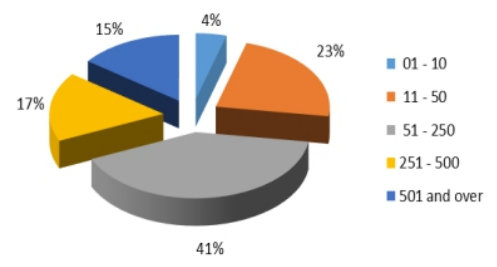

Figure 6. Mexican footwear-importing firms by number of employees (2013)

Source: Authors' elaboration

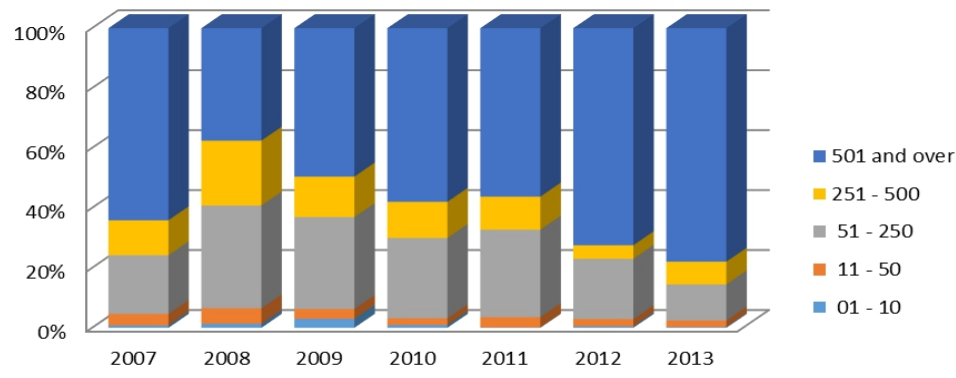

Figure 7. Mexican footwear volume imports (thousands of USD) by number of employees (2007-2013)

Source: Authors' elaboration

Derived from the analysis of this information presented in Figure 7, it can be observed that large footwear importing firms (251-500 employees and $501->$ ) had also become more important through period 2007-2013, as it occurred with exporting firms. In 2008 when the international financial crisis begun, imports fell around 33\%, less than the export activity; one of the reasons is that an origin market of imported products is Asia. But it is 
meaningful to observe that until 2012, only the largest companies in terms of employees (250- > category) were able to reach their 2007 import levels and for 2013, no other group of footwear industry have had this recovery capacity. Therefore, this makes it possible to affirm that although the imports fall was initially lower, the effects were greater due to the recovery time.

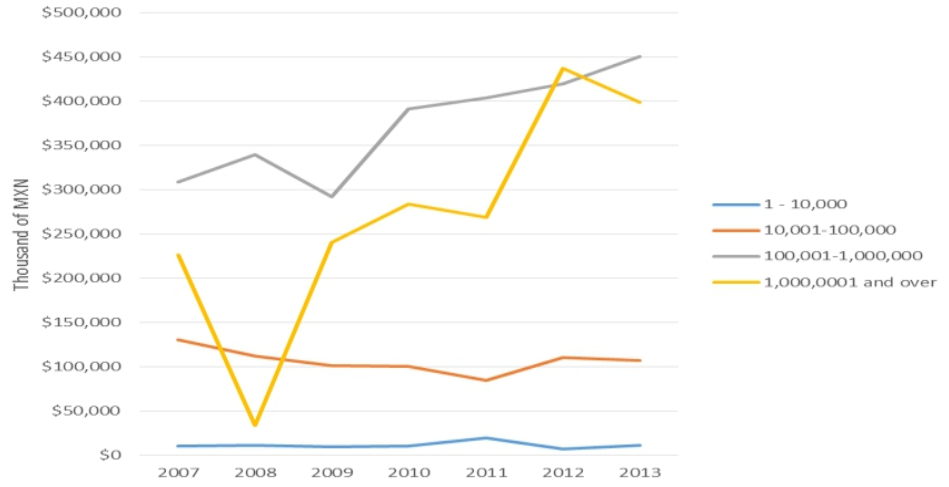

Figure 8. Mexican footwear volume exports (thousands of $\mathrm{MXN}$ ) by value of production (2007-2013)

Source: Authors' elaboration

Figure 8 shows that the firms with a volume of exports of 1-10,000 and $10,001-100,000$ Mexican pesos (MXN) are the most stable and constant based on their tendency over time. However, during the period 2007-2013, the first group (1-10,000) growth of around $12 \%$ was quite poor. For the second group $(10,001-100,000)$, it registered a fall of $18 \%$. The 100,001-1,000,000 group is the strongest of the studied period because it registered a growth all years, except in 2009. Finally, and despite being the group of higher production $(1,000.001$ and $>)$, its affectation of $85 \%$ was the biggest in 2008 . However, a recover of the level of exports reached the following year, but that fall evidences the exposure when the market is so concentrated.

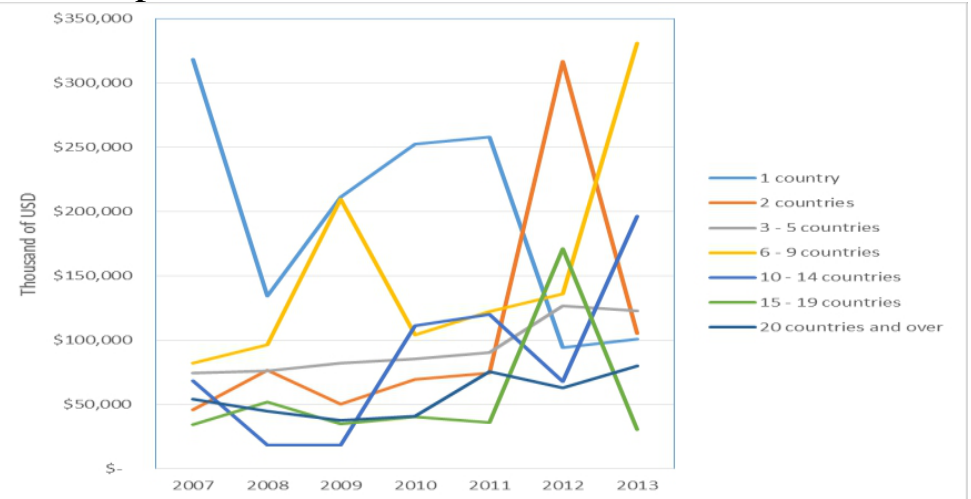

Figure 9. Mexican footwear volume exports (thousands of MXN) by market diversification (2007-2013)

Source: Authors' elaboration 
Information presented in Figure 9 confirms the negative effects of market concentration. It is evident that firms that only export to one market was much more affected compared to those that export their products to more than one country. In the case of Mexican exporters, the main market is often USA. Indeed, the first group ( 1 country) is the only one that has not registered a growth in their exports during studied period. In 2013, it exported less than one third of the 2007 volume exports. The main implication of this is not only the necessity, but also the urgency to increase market diversification for firms that try to be competitive in global markets. In these markets, crisis appeared regularly in different regions of the world.

It is worthy to mention that an excessive market diversification seems not to be recommendable since the firms that export to 15-19 countries registered a fall of $11 \%$ during 2007-2013 and those that exported to 20 - > countries registered a growth of $48 \%$. Although the latter may be seen as a good result, it is not when compared to the growth of $131 \%$ reached by the 2 countries category, $66 \%$ by $3-5$ countries category, $304 \%$ by $6-9$ countries category, and $188 \%$ by $10-14$ countries category.

Without the pretension to establish a rigid rule and given the dataset analyzed, it is observed that for an exporting firm in this industry, to have from 2 to 14 different markets seems to be the best option.

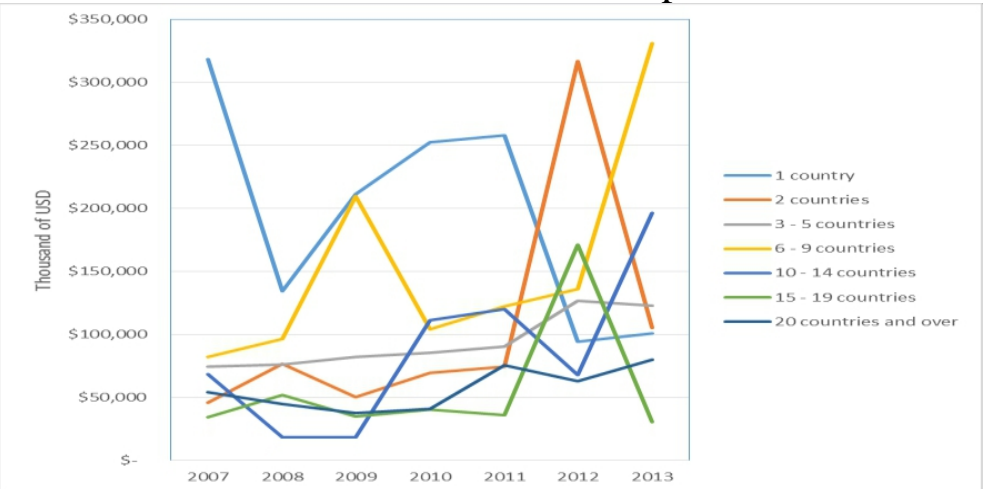

Figure 10. Mexican footwear volume imports (thousands of MXN) by value of production (2007-2013)

Source: Authors' elaboration

Figure 10 shows that the firms with annual production of 1-10,000 and 10,001-100,000 Mexican pesos (MXN) are also the most stable and constant based on their tendency over time. Thus, this was similar to what was represented in Figure 6. The remarkable fact of this figure is that for the importing activity, the 1,000,001 - > group had a growth of $77 \%$ being the only category that is over the 2007 level imports. Thus, the import activity is 
concentrated in large companies that take advantage of the accesses to foreign products to satisfy specific needs of price or quality.

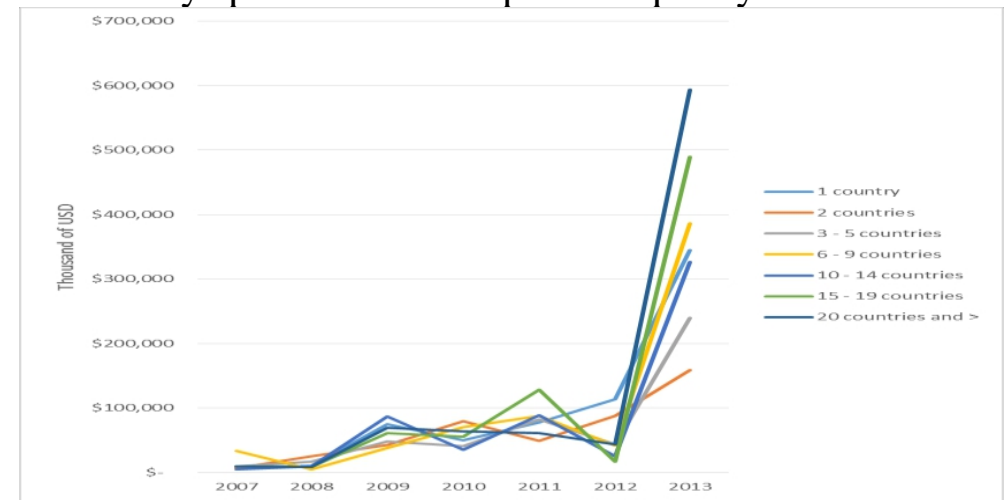

Figure 11. Mexican footwear volume imports (thousands of MXN) by market diversification (2007-2013)

Source: Authors' elaboration

Figure 11 shows a generalized growth of the levels of imports during 2007-2013. Particularly in 2013, there was a considerable increase in the level of imports that is explained by the exchange variation of the Mexican peso against the US dollar.

\section{Model Specification}

\subsection{Total Productivity Factor (TPF)}

The measurement of the productivity of the different factors involved in the production process has been contemplated in the agenda of economic issues. In his work, Solow (1957) proposed a practical way of measuring the productivity. This measurement is carried out by estimating a residual, which is used to represent the increase or decrease of the production. Nevertheless, this is not explained by the increase or decrease of the different factors involved in productivity (capital and labor in first place) and which can be associated with the term "productivity of factors" that we know nowadays.

Later developments incorporated methods to measure this residual that incorporates other factors such as energy, materials, and services. These developments are concentrated on what is known as growth accounting (Bureau of Labor Statistics, 1982), in which by the construction of index numbers, the residual and the contributions to the growth of the factors involved in production can be estimated.

Table 1 included in this study presented the contributions of the growth of the factors involved in the production process, as well as the contribution of each of them: capital and work. This, therefore, takes into account the incorporation of more factors methodologically limited such as energy, materials and services, as well as the total productivity of the factors related 
to the growth of the value of production in terms of constant values at 1995 prices (INEGI, Statistical Institute for Geography, Statistics and Informatics 2014).

Table 1. Production of Mexican Footwear Industry

\begin{tabular}{lcc}
\hline & Production Value & Total Productivity Factor \\
\hline $\mathbf{2 0 0 7}$ & -1.61 & -2.1 \\
$\mathbf{2 0 0 8}$ & -3 & -2.98 \\
$\mathbf{2 0 0 9}$ & -4 & -3.09 \\
$\mathbf{2 0 1 0}$ & 9 & 2.78 \\
$\mathbf{2 0 1 1}$ & -1.74 & -1.41 \\
\hline
\end{tabular}

Source: Authors' elaboration

\subsection{Sources of Information}

To calculate the TPF, the following sources of information were considered:

- Publications of Goods and Services Accounts (CBYS) of the National Accounts System of Mexico (SCNM). This is the main source of information by providing data of the main economic variables and the jobs.

- Monthly Industrial Survey 1989-2009, applied and published by the National Institute of Geography, Statistics and Informatics of Mexico.

- Monthly Manufacturing Industry Survey 2007-2011, applied and published by the National Institute of Geography, Statistics and Informatics of Mexico.

- Annual Industrial Survey 1989-2009, applied and published by the National Institute of Geography, Statistics and Informatics of Mexico.

- Annual Manufacturing Industry Survey 2008-2011, applied and published by the National Institute of Geography, Statistics and Informatics of Mexico.

- Trade, services and construction companies' surveys, applied and published by the National Institute of Geography, Statistics and Informatics of Mexico.

- Economic censuses 1993, 1998 and 2003, applied and published by the National Institute of Geography, Statistics and Informatics of Mexico.

- National Employment Survey (ENE) 1988, 1991 and 1995-2004, applied and published by the National Institute of Geography, Statistics and Informatics of Mexico.

- National Survey of Occupation and Employment (ENOE) 20052011, applied and published by the National Institute of Geography, Statistics and Informatics of Mexico. 
- Supply and Use Tables 2003 (COU), published by the National Institute of Geography, Statistics and Informatics of Mexico.

- Input Matrix Product 2003, applied and published by the National Institute of Geography, Statistics and Informatics of Mexico.

- Minimum Salaries of the National Minimum Salaries Commission Minima.

- The balance of payments, 1989-2011 series, published by the Bank of Mexico.

- Producer and Consumer price indices, series 1989-2011; from the Bank of Mexico

- Finally, the Administrative Records of several companies, considered by the National Institute of Geography, Statistics and Informatics of Mexico.

Traditional sources of economic growth are capital (K) and labor (L). Therefore, emphasis on the importance of both the quantity of used factor, and its contribution to the growth product has been highlighted. In addition to capital and work, the contribution of the intermediate inputs used in production, considering energy (E), Materials (M) and Services (S), are incorporated in the measurement of Total Productivity Factor (TPF).

The capital factor is formed by ICT (Information and Communication Technologies) and by non-ICT assets. For the labor factor, eighteen different typologies have been considered, corresponding to work hours, identified by sex, 'male' and 'female', by age groups, '15-29', '30-49' and 'over 50', and disaggregated by levels of schooling: 'low' which corresponds to primary education, 'half up' which corresponds to High school, and 'high' which corresponds to higher education.

Considering these factors, within the conceptual framework of growth accounting and the LA-KLEMS Model, the TPF was estimated in order to know the participation and contribution to the product of the various factors. All calculations are performed over time for reasons of exposure, the time subscripts. The KLEMS model is based on a function of production of the form:

$$
\int(x)=(K, L, E, M, S)
$$

A change in the product can be expressed as follows:

$$
\Delta Y=\alpha \Delta K+\beta \Delta L+\gamma \Delta E+\varepsilon \Delta M+\theta \Delta S+\Delta A
$$

Where K, L, E, M, S mean capital, labor, energy materials and services, respectively. The $\Delta$ symbol means growth; the greek letters $\alpha, \beta, \gamma, \varepsilon, \theta$ are the contributions of factor considered in the production value; and letter $\mathrm{A}$ is the indicator of the TPF. 
In order to obtain the TPF indicator as a residual, the weighted variations of the factors mentioned above are subtracted from the value production change:

$$
\Delta A=\Delta Y-\alpha \Delta \mathrm{K}-\beta \Delta L-\gamma \Delta E-\varepsilon \Delta M-\theta \Delta S
$$

TPF considers technological change, innovations techniques, changes in the way of administration and organization of enterprises, as well as changes in the social composition.

\subsubsection{Methodology}

The objective of this study is to measure the correlation, using the Pearson factor, between the enterprise evolution during the analyzed period (2007-2013), the total production value of the industry, and the total productivity factors (considering LA-KLEMS Model). Moreover, detailed firm level dataset from the Mexican leather footwear industry is provided to represent how every group of firms is differently correlated with the selected variables (firms are categorized by number of employees into five groups: '010', '11-50', '51-250', '251-500' and '501 and more'; by annual value of production into four categories: '1-10,000 USD', '10,0001-100,000 USD', '100,0001-1,000,000 USD' and '1,000,001 USD and more'; and by commercial diversification into 6 categories: 'trade with 1 country', 'trade with 2 countries', 'trade with 3-5 countries', 'trade with 6-9 countries', 'trade with 10-14 countries', 'trade with 15-19 countries', and ' trade with 20 and more countries').

The methodology to calculate the capital services is based on the study of OECD (2009). In this document, it was recommended to start the calculation of these services by identifying some investment data: formation brute of capital fixe (FBKF). Referencing the series of the investment to a specific year allows to have the stock in comparable and referenced 'efficiency units' to a specific year.

The FBKF by destination in constant values of the basis year is used in the application of the perpetual inventories to obtain the stock of capital net total or stock wealth. It starts with the obtaining of the initial stock:

Stock inicial $=F B K F_{\text {inicial }} /\left(T C_{F B K F}+\delta\right)$

Where:

$T C_{F B K F}=$ Long-term growth rate

$\delta=$ Depreciation rate

The depreciation rate used in this method is calculated through the double decline that relates the useful lives of the assets with a coefficient of decline. However, this rate is used in the rest of the calculations.

The total capital stock is calculated as follows:

$W^{R}=W^{I}+F B K F-\delta\left(F B K F+W^{I}\right)$

Where: 
$W^{R}=$ Total capital stock

$W^{I}=$ Initial capital stock

$F B K F=$ Formation brute of capital fixe

$\delta=$ Depreciation rate

Obtaining the total stock, the next step is to calculate the productive stock that is considered as part of the total stock participating in the production.

$$
K^{t}=F B K F+W^{R}
$$

Where:

$K^{t}=$ Production stock

To complete the calculation of the capital services, it is necessary to estimate a rental price of capital (Cost of user or use). This price is not obtained directly because it is difficult to know the price of income from second-hand capital assets. Besides, the owner of the capital goods often is also the producer himself and the price is unknown. Therefore, it is necessary to estimate it. This process begins by obtaining the rate of return on capital (Endogenous) for economic activities involved in this project:

$$
r=\frac{\left\{\frac{S B O+T}{I P C}-\Sigma_{k=1}^{N}[\delta(1+i)-i] K\right\}}{\Sigma_{k=1}^{N} K}
$$

Where:

$S B O=$ Gross operation surplus

$I P C=$ Consumer price index

$T=$ Others taxes

$\delta=$ Depreciation rate

$i=$ FBKF prices index

$K=$ Production stock

With the obtained rate of return, then the user cost is calculated followed by the capital services using the following equation:

$U=(I P C)[r+\delta(1+i)-i] K$

Where:

$U=$ User cost

$r=$ Return rate

$\delta=$ Depreciation rate

$i=$ FBKF prices index

$K=$ Production stock

Finally, in the construction of the capital services indices, the user cost is considered as a weight. Being the productive stock, the indicator of the variation of each asset to construct Laspeyres type chained volume indexes and Paasche, serves as a basis for forming the Fisher ideal index:

$I S k_{F}=\sqrt{I S k_{L} * I S k_{P}}$

Where: 
$I S k_{F}=$ Capital services Fisher index

$I S k_{L}=$ Capital services Laspeyres index

$I S k_{P}=$ Capital services Paasche index

\subsubsection{Labor Services}

When estimating productivity, it is recommended to measure the input labor without considering the number of people. However, the measurement of hours worked is given that: 'For each one of the worker categories, it is assumed initially that the flow of labor services is proportional to hours worked' (Jorgenson Dale W. s.f.).

Derived from the above, it is clear that for the measurement of labor services, a flexible chained index that takes into account the average of two underlying periods was constructed:

$S L=\sum_{i=1}^{n} \frac{1}{2}\left[\frac{\left(w_{t} * H_{t}+w_{t-1} * H_{t-1}\right)}{\sum w_{t} * H_{t}+\sum w_{t-1,} H_{t-1}}\right]\left(\frac{H_{t}}{H_{t-1}}\right)$

Where:

$S L=$ Labor services index

$w=$ Salary per hour

$H=$ Work hours

This equation shows how the labor services was calculated, considering the following: Weighting of the worked hours worked by the participation of each breakdown of labor (gender, age and schooling) in the total remuneration for the studied period $(\mathrm{t})$ and the previous period $(\mathrm{t}-1)$ multiplied by the simple variation of worked hours.

After analyzing and securing the capital and labor productivity factors, and intermediate inputs, the next step is to estimate the TPF starting from the growth of the production value and the contribution of capital services opened to ICT and non-ICT assets; labor services, by age groups and levels of scholarship; and the opening of energy, materials, and services intermediate inputs.

Subsequently, the residual or TPF was calculated from growth of the production value and the difference with the total contribution of the productive factors.

In general, when analysing separately the tendency of the production value and weight contributions of the components: Capital services (K), Labor services (L), Energy (E), Materials (M) and Services (S), it was observed that the growth or fall of TPF is mainly determined by the production tendency.

In conclusion, it can be observed that the growth of TPF is negative in almost all the years. It is determined by the small growth of the production value associated with growth in capital services and labor services that reduce the residual, i.e. Total productivity factor (TPF). It was also observed that a growth in the input does not necessarily generate a growth in production, 
which leads to a study in details in regards to the way to foment the total productivity factors.

\subsection{Results of Pearson Correlation Coefficient Calculations}

Table 2 summarized the Pearson Correlation Coefficients obtained for the relationship between production value to exporting and importing firms respectively. Also, the total productivity factor to total exports and also imports was also presented.

Table 2. Pearson Correlation Coefficients, Mexican Leather Footwear Industry (2007-2011)

\begin{tabular}{|c|c|c|c|c|}
\hline $\begin{array}{l}\rho \\
\text { value } \\
\text { firms) }\end{array}$ & $\begin{array}{l}\text { (Production } \\
-\quad \text { exporting }\end{array}$ & 0.4915 & 0.7028 & $\rho(\mathrm{TPF}-$ exports) \\
\hline $\begin{array}{l}\rho \\
\text { value } \\
\text { firms) }\end{array}$ & $\begin{array}{l}\text { (Production } \\
\text { - importing }\end{array}$ & 0.3219 & 0.6511 & $\rho$ (TPF - imports) \\
\hline
\end{tabular}

Source: Authors' elaboration

Table 3 indicates that firms of the ' $51-250$ ' and the ' 501 and >' groups have a strong correlation to the exports. It is interesting to notice that the ' 251 500 ' group has a weaker correlation to that same variable, different from expected result. Additionally, the '01-10' group has a stronger correlation than the ' $11-50$ ' group. These results seem to imply that the correlation of '01-10' and ' $11-50$ ' groups is nonlinear to exports.

Table 3. Pearson Correlation Coefficients, Exports - Exporting firms by number of employees (2007-2011)

\begin{tabular}{lccccc}
\hline Description & $01-10$ & $11-50$ & $51-250$ & $251-500$ & 501 and $>$ \\
\hline $\begin{array}{l}\text { exporting } \\
\text { firms) }\end{array}$ & 0.3547 & 0.1192 & 0.8593 & 0.5423 & 0.9591 \\
\hline
\end{tabular}

Source: Authors' elaboration

Table 4 shows that ' 501 - $>$ ' group have a very strong correlation to average exports which can be easily explained by the competitiveness and acquired knowledge by the firms of this category. The results of ' $11-50$ ' and '51-250' categories have almost the same magnitude in absolute values, but opposite direction. Thus, an increase or decrease in any of the variables has a contrary effect for each group.

Table 4. Pearson Correlation Coefficients; Average exports - Exporting firms by number of employees (2007-2011)

\begin{tabular}{llllll}
\hline Description & $01-10$ & $11-50$ & $51-250$ & $251-500$ & 501 and $>$ \\
\hline $\begin{array}{l}\rho \quad \text { average } \\
\text { exports }-\end{array}$ & -0.2373 & -0.5182 & 0.5983 & 0.1535 & 0.918 \\
$\begin{array}{l}\text { exporting } \\
\text { firms) }\end{array}$ & & & & & \\
\hline
\end{tabular}


Table 5 indicates that the ' $100,001-1,000,000$ ' group has a stronger correlation to exports than the ' $1,000,001$ - $>$ ' group which is different from the expected result. In fact, the result of the ' $1,000,001->$ ' group is almost of the same magnitude than the ' $1-10,000$ ' group.

Table 5. Pearson Correlation Coefficients, Exporting firms by number of employees Exports (2007-2011)

\begin{tabular}{lllll}
\hline Description & $1-10000$ & $10,001-100000$ & $100,001-1,000,000$ & $1,000,001->$ \\
\hline$\rho($ exporting & & & & \\
firms -0.4401 & 0.0611 & 0.9144 & 0.4703 \\
exports) & & & & \\
\hline
\end{tabular}

Source: Authors' elaboration

Table 6 shows that the '10-14 countries' category by diversification market has the strongest correlation to exports. The difference from the ' 1 country' category is not so considerable, but the risk for this category of reduced exports during crisis time is extremely high as shown in Figure 9.

Table 6. Pearson Correlation Coefficients, Exporting firms by diversification market Exports (2007-2011)

\begin{tabular}{cccccc}
\hline Description & 1 country & 2 countries & $3-5$ countries & $6-9$ countries & $10-14$ countries \\
\hline $\begin{array}{l}\rho \text { (diversification } \\
\text { market - exports) }\end{array}$ & 0.5173 & 0.0267 & 0.2115 & 0.1332 & 0.7749 \\
\hline
\end{tabular}

Source: Authors' elaboration

Table 7 demonstrates that Pearson Correlation Coefficients Imports Importing firms for all the groups ('01-10'- '11-50', '51-250', '251-500' and '501 - >') are very strong. This is more than the obtained result for the exporting activity of the Mexican footwear leather industry. Therefore, it is necessary to promote the exports and to reorient the type of imported products to create products of more added value to strengthen this industry.

Table 7. Pearson Correlation Coefficients, Imports - Importing firms by number of employees (2007-2011)

\begin{tabular}{lccccc}
\hline Description & $01-10$ & $11-50$ & $51-250$ & $251-500$ & $501->$ \\
\hline $\begin{array}{l}\rho \quad \text { (imports } \\
\text { importing firms) }\end{array}$ & 0.8246 & 0.7559 & 0.6692 & 0.7384 & 0.7665 \\
\hline
\end{tabular}

Source: Authors' elaboration

Table 8 shows that the average imports correlation to average imports is negative for the ' $1-10$ ' and ' $11-50$ ' groups, while it is positive for the rest of the groups. It was observed that for the ' $50-250$ ' group, the relation is almost perfect. 
Table 8. Pearson Correlation Coefficients, Average imports - Importing firms by number of employees (2007-2011)

\begin{tabular}{llllll}
\hline Description & $01-10$ & $11-50$ & $51-250$ & $251-500$ & $501->$ \\
\hline$\rho \quad$ (average & & & & & \\
$\begin{array}{l}\text { imports } \\
\text { importing firms) }\end{array}$ & -0.0835 & -0.1752 & 0.95 & 0.5629 & 0.6045 \\
\hline
\end{tabular}

Source: Authors' elaboration

Table 9 indicates that correlation coefficients are negative for the ' 1 10,000 ', the '10,001-100,000'and the '100,001-1,000,000' categories, and only positive for the ' $1,000,001$ - $>$ ' category. This demonstrates that this group is the best to be objective of importing reorientation activity.

Table 9. Pearson Correlation Coefficients, Importing firms by value of production - Imports (2007-2011)

\begin{tabular}{lllll}
\hline Description & $1-10000$ & $10,001-100000$ & $100,001-1,000,000$ & $1,000,001->$ \\
\hline $\begin{array}{l}\rho \text { (importing firms } \\
\text { - imports) }\end{array}$ & -0.6154 & -0.7133 & -0.8037 & 0.821 \\
\hline
\end{tabular}

Source: Authors' elaboration

Finally, Table 10 shows that market diversification seems to be more important for importing activity than for exporting activity even for the '1014 countries' group and for the '20 - > countries' group. Therefore, the importing firms correlation to imports is negative.

Table 10. Pearson Correlation Coefficients, Importing firms by diversification market Imports (2007-2011)

\begin{tabular}{llll}
\hline Description & 1 country & 2 countries & 3 - 5 countries \\
\hline $\begin{array}{l}\rho \quad \text { (diversification } \\
\text { market - imports) }\end{array}$ & 0.7247 & 0.6048 & 0.5055 \\
\hline $\begin{array}{l}\text { Description } \\
\begin{array}{l}10- \\
\text { countries }\end{array}\end{array}$ & $\begin{array}{l}15- \\
\text { countries }\end{array}$ & $20->$ countries \\
\hline $\begin{array}{l}\rho \quad \text { diversification } \\
\text { market - imports) }\end{array}$ & -0.1924 & 0.7108 & -0.2242 \\
\hline
\end{tabular}

Source: Authors' elaboration

\section{Conclusion}

The main implications of the obtained results are the following: Firstly, the correlation of production value with the number of exporting companies $(0.4915)$ is bigger than the correlation with the importing companies $(0.3219)$. Then, the production value is an indicator that must be monitored carefully specially by the Mexican Government that, in recent years, has developed policies to promote the exports of leather-manufactured footwear. The relation between the production value and the number of importing companies seems to be less strong. In addition, it eventually does not influence directly the increase of the competitiveness of the sector, except when considering the import of raw materials, which is not the case presented in this paper. 
Secondly, the correlation of Total Productivity Factor to the volume of exports is strong (0.7028) and derived from this. Therefore, it is possible to consider it as a very important factor to pay attention at in order to get a higher level of competitiveness of the industry. The implication of this result shows that industry and institutional efforts must be directed to encourage the exporting activity, mainly in companies of medium size. This is because small companies might be immature to compete in some markets, and also try to sell their products in a wide range (2-14) of countries.

Thirdly, the correlation of Total Productivity Factor to imports (0.6511) is also significant and has to be considered when a strategy of use of raw material at low cost is developed to build an additional competence in the global market.

Finally, if a more diversified offer of products is available in the Mexican domestic market, strengthened by the importation of good quality products, the competitive capacity of the Leather-footwear industry will be increased and able to compete better in the global market.

\section{References:}

1. AGA General Customs Administration (2015). Retrieved from http://www.sat.gob.mx/que_sat/Paginas/aduanas.aspx.

2. Aghion, P. et al. (2005). Competition and Innovation: An Inverted U Relationship? Quarterly Journal of Economics 120 (2), 701-728.

3. Aghion, P. \& Howitt, P. (2009). The Economics of Growth Massachussets : MIT Press.

4. APICCAPS Portuguese Footwear, Components and Leather Goods Manufacturers' Association (2015). World Footwear Yearbook Porto: APPICAPS.

5. Awokuse, T. O. (2008). Trade openness and economic growth: is growth export-led or import-led? Applied Economics (Taylor and Francis Journal), 40 (2), 161-173.

6. Bernard, A. B. et al. (2007). Firms in International Trade Journal of Economic Perspectives, 21(3), 105-30.

7. BLS Bureau of Labor Satistics (1982). The measurement of productive capital stock, capital wealth, and capital services. BLS working paper 128.

8. CEPAL Economic Commission for Latin America and the Caribbean (2016). LA-KLEMS: opening toward Latin America WORLD-KLEMS project". Retrieved from: http:/www.cepal.org/cgibin/getprod.asp?xml=/laklems/noticias/paginas/9/40269/P40269.xml \&xsl=/la-klems/tpl/p18f-st.xsl\&base=/la-klems/tpl/top-bottom.xsl.

9. CICEG Chamber of the Footwear Industry of Guanajuato State (2011). Mexican Footwear Industry Situation. Leon: CICEG. 
10. CICEG Chamber of the Footwear Industry of Guanajuato State (2015). Newletter. Leon: CICEG.

11. Esfahani, S. H. (1991). Exports, imports, and economic growth in semi-industrial countries Journal of Development Economics, 35, 93116.

12. Geo-Mexico Geography and Dynamics of Modern Mexico (2014) Retrieved from: http://geo-mexico.com/?p=11164.

13. Geo-Mexico Geography and Dynamics of Modern Mexico (2011) Retrieved from: http://geo-mexico.com/?p=3265.

14. Grossman, G. M. \& Helpman, E. (1991). Innovation and growth in the global economy. Cambridge, Massachusetts: MIT Press, 1991.

15. Ifwarsson, R. (2010). Export, Import, Productivity and Growth: A theoretical and empirical study of an endogenous relationship. Lund University: Department of Economics.

16. INEGI National Institute of Geography, Statistics and Informatics (2013). Profile of export manufacturing companies 2007-2010. Mexico: INEGI.

17. INEGI National Institute of Geography, Statistics and Informatics (2014). «Profile of export manufacturing companies 2010-2013. Mexico: INEGI.

18. INEGI National Institute of Geography, Statistics and Informatics (2014). Statistics of the footwear industry. Mexico: INEGI, 13, 23.

19. INEGI National Institute of Geography, Statistics and Informatics (2014). SCNM National Accounting System of Mexico. Total Productivity Factor TPF. KLEMS Model. Aguascalientes: INEGI.

20. Jorgenson D. W. \& Stiroh, K. J. (n. d.). Raising the speed limit: U.S.: U. S. economic growth in the information age (OECD economics department working papers), 261.

21. Krugman, P., Obstfeld, M. \& Melitz, J. M. (2002). "International Economics: Theory and Policy". 6th Edition. Wesley: Pearson Education Limited Addison.

22. Krugman, P. (1994). Competitiveness: A dangerous obsession. Foreign Affairs, 28-44.

23. Kuepper, J. (2016). How Globalization Impacts International Investors. International Investing. Retrieved from: https://www.thebalance.com/globalization-and-its-impact-oneconomic-growth-1978843

24. Kunst, R. M. \& Marin, D. (1989). On exports and productivity: A causal analysis. Review of Economics and Statistics 71(4), 669-703.

25. Muuls Mirabelle \& Mauro Pisu (2009). "“Imports and Exports at the level of the firm: Evidence from Belgium”.» 32, n 5: 692-75. 
26. OECD Organization for Economic Cooperation and Development (2009). Measuring capital Manual.

27. OECD Organization for Economic Cooperation and Development (2014). Glosssary of Statistical Terms. Retrieved from: https://stats.oecd.org/glossary/detail.asp?ID=399.

28. Porter, M. E. (1998). On Competition. New York: The Free Press.

29. Porter, M. E. (1990). The Competitive Advantage of Nations. New York: The Free Press.

30. Scott, A. J. (ed.) (2001). Regions and the New Economics of Competition.

31. Oxford: Oxford University Press.

32. Romer, P. Endogenous Technological Change Journal of Political Economy 98(5), 71-102.

33. Seker, M. (2011). Importing, Exporting, and Innovation in Developing Countries.

34. Solow, R. M. (1957). Technical change and the aggregate production function" Review of economics, 39, 312-320.

35. Tradegood. (2013). Retrieved from: http://www.tradegood.com/es/viewpoints/the-textile-and-footwearindustries-in-mexico.html

36. Vogel, A. \& Wagner, J. (2010). High Productivity in Importing German Manufacturing Firms: Self-Selection, Learning from Importing or Both? Review of World Economics. Springer Verlag, 145 (4), 641-665. 